\title{
An Assessment of Youth Involvement in Agricultural Activities in Eastern Cape Province, South Africa
}

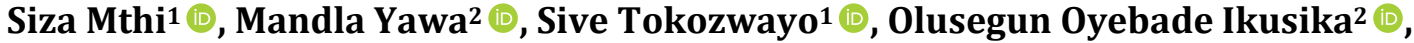

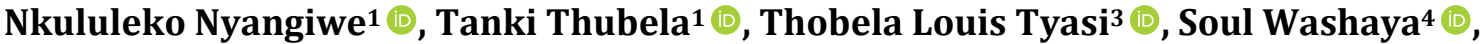 \\ Masibonge Gxasheka ${ }^{5}$ (), Zuko Mpisana ${ }^{2}$, Msimelelo Buyisile Nkohla ${ }^{6}$ (i)
}

\footnotetext{
${ }^{1}$ Department of Rural Development and Agrarian Reform, Döhne Agricultural Development Institute, Stutterheim, South Africa ${ }^{2}$ Department of Livestock and Pasture Science, University of Fort Hare, Alice, South Africa

${ }^{3}$ Department of Agricultural Economics and Animal Production, University of Limpopo, Polokwane, South Africa

${ }^{4}$ Department of Livestock, Wildlife \& Fisheries Great Zimbabwe University, Masvingo, Zimbabwe

${ }_{5}^{5}$ Department of Plant Production, Soil Science \& Agricultural Engineering, University of Limpopo, Polokwane, South Africa

${ }^{6}$ Faculty of Education, School of Further \& Continuing Education, University of Fort Hare, Alice, South Africa

Email: sizamthie@gmail.com
}

How to cite this paper: Mthi, S., Yawa, M. Tokozwayo, S., Ikusika, O.O., Nyangiwe, N., Thubela, T., Tyasi, T.L., Washaya, S., Gxasheka, M., Mpisana, Z. and Nkohla, M.B. (2021) An Assessment of Youth Involvement in Agricultural Activities in Eastern Cape Province, South Africa. Agricultural Sciences, 12, 1034-1047.

https://doi.org/10.4236/as.2021.1210066

Received: August 8, 2021

Accepted: October 5, 2021

Published: October 8, 2021

Copyright $\odot 2021$ by author(s) and Scientific Research Publishing Inc. This work is licensed under the Creative Commons Attribution International License (CC BY 4.0).

http://creativecommons.org/licenses/by/4.0/ (c) (i) Open Access

\begin{abstract}
Youth, who make up the majority of South Africa's population and will be the future responsible citizens, confront numerous obstacles, including a lack of access to land, finance, markets, practical training, and incentives. The low interest of youngsters in agriculture is attributed to the poor status of agricultural output in Africa's rural areas due to a lack of government support. The study was conducted to assess the involvement of youths in agricultural activities in Eastern Cape Province, South Africa. The convenient sampling technique was used, and qualitative data were collected from 104 participants using a pre-tested structured questionnaire. The questionnaire covered demographic characteristics, land ownership status, contact with extension personnel, and involvement in farming activities, funding, and constraints. Descriptive statistics and chi-square test were used for data analysis. The results showed that there were more males (59.6\%) participants than females (40.4\%) and the majority (74\%) were between 20 - 35 years of age, $52.9 \%$ had senior secondary school level of education and came from a household size ranging from 6 - 19. Approximately $88.5 \%$ of participants had an agricultural background with an annual income of less than R20,000.00. More than half (51.9 \%) of the study population, had farming experience less than 5 years, while $52.9 \%$ owned less than 2 hectares of land, and $78.8 \%$ were self-employed. Findings revealed that age $\left(\chi^{2}=5.519, \mathrm{P}<0.01\right)$ and farming experience $\left(\chi^{2}=\right.$ 43.981, $\mathrm{P}<0.001)$ had a significant association with extension contact and
\end{abstract}


farming enterprises respectively. Furthermore, lack of land ownership, high input costs, access to credit, visibility of extension personnel, lack of market access, low returns, high cost of mechanization, and lack of farming knowledge were the most ranked constraints hindering youth involvement in agricultural activities. Youth involvement in agricultural activities can be improved through land availability, financial support, and information dissemination on rural development programs by extension personnel.

\section{Keywords}

Agriculture, Land Ownership, Livelihood, Youth, Market Access

\section{Introduction}

Agriculture is an important sector for the economic sustainability and social wellbeing of all developing countries across the globe [1] [2]. In most developing countries bulk of the agricultural production efforts are still left in the hands of aged farmers who presently constitute the major farming population [3] in Southern Africa. The elders' agricultural productivity level cannot meet the speedily growing population's food and fibre needs [2] [4]. Additionally, the new ideas and techniques used to improve agricultural production are not user-friendly for most older people and illiterate. Subsequently, fostering youth involvement in agriculture remains vital to economic development in most developing countries. Therefore, youth remains an important and essential part of human resources that can carry the responsibility of development, including agriculture [5], and overcome some of the significant constraints to expand agricultural production in developing countries [6].

According to [7] [8], more than $50 \%$ of the population in South Africa depends on agriculture for their livelihoods, of which $36.2 \%$ are young people in the age range of 18 - 35 years [9]. Agriculture has been identified as one of the sectors that have the greatest potential to create jobs for youth in sub-Saharan Africa (S.S.A.) [10]. Youth, which are the main bulk of the population in South Africa and responsible citizens of tomorrow, face many challenges such as lack of access to land, finance, markets, practical training, and incentives. The poor state of agricultural production due to lack of government support in the rural areas in Africa has resulted in the low interest of youth in agriculture. Lack of support system available to support youth made them not take advantage of the various opportunities that the government has instituted [11] [12]. According to [13] mid-term report, about $30 \%$ and $19.4 \%$ of South Africa youth live in Gauteng and Kwa-Zulu Natal province, respectively. The Free State (4.7\%) and Northern Cape (2\%) are the least populated provinces by youth. The mere fact that Eastern Cape does not appear as a populated province by youth means that most youths in the province migrate to urban areas [14]. Gauteng looks for bet- 
ter jobs than agriculture, and some are involved in delinquent activities such as drug abuse and stealing. However, the high unemployment rate and poverty are among youth's challenges and causing high youth migration to another province to look for better opportunities.

Therefore, agricultural growth can weaken poverty directly by increasing youth agricultural farming activities (i.e., generating more income) and indirectly, through labour markets and reducing food prices [15]. To foster a country's economic development, youth should be encouraged to participate in agricultural activities because they constitute an important component in society and are the greatest assets of any country globally [16]. According to [17], youth constitute an important resource for sustaining agricultural productivity, essential for economic development and growth. Although a lot of research has been conducted on youth involvement in agriculture, there is still a lack of research that seeks to evaluate rural youth participation in agricultural activities, particularly in the Eastern Cape Province in South Africa. Consequently, the significance and constraints of rural youth participation in agriculture remain poorly understood. The study aimed to assess youth participation in agricultural activities in rural communities of Eastern Cape, South Africa.

\section{Materials and Methods}

\subsection{Description of the Study Sites}

The study was carried out in five villages situated in Amahlathi, Mbhashe, Mnquma, Ngcobo, and Ngquza Hill municipalities, Eastern Cape Province. This included Upper Ngqumeya, Ku-Bafazi, Dudumashe, Ntibane and Goso shown in Figure 1 and Table 1 . A Convenient sampling technique was used to select villages based on youth involvement in agricultural activities and the respondents' willingness to participate in the study.

\subsection{Data Collection}

A total of 104 respondents were interviewed using a pre-tested structured questionnaire, from October 2012 to February 2014. The questionnaire covered

Table 1. Description of the survey study sites.

\begin{tabular}{|c|c|c|c|c|c|}
\hline Village & Upper-Ngqumeya & Ku-Bafazi & Dudumashe & Ntibane & Goso \\
\hline \multirow{2}{*}{ Co-ordinates } & $32^{\circ} 43^{\prime} 87^{\prime \prime} \mathrm{S} \&$ & $32^{\circ} 02^{\prime} 54^{\prime \prime S} \&$ & $32^{\circ} 08^{\prime} 38^{\prime \prime} \mathrm{S} \&$ & $31^{\circ} 38^{\prime} 54^{\prime \prime S} \&$ & $31^{\circ} 22^{\prime} 38^{\prime \prime} \mathrm{S} \&$ \\
\hline & $27^{\circ} 07^{\prime} 14^{\prime \prime} \mathrm{E}$ & $28^{\circ} 54^{\prime} 19^{\prime \prime} \mathrm{E}$ & $27^{\circ} 56^{\prime} 56^{\prime \prime} \mathrm{E}$ & $28^{\circ} 17^{\prime} 79^{\prime \prime} \mathrm{E}$ & $29^{\circ} 35^{\prime} 57^{\prime \prime} \mathrm{E}$ \\
\hline Vegetation type & Amathole Montana & Bhisho Thornveld & $\begin{array}{c}\text { Drakensberg Foothill } \\
\text { Moist Grassland }\end{array}$ & Mthatha Coastal Belt & Ngongoni \\
\hline Temperature $\left({ }^{\circ} \mathrm{C}\right)$ & $5.3-32.3$ & $9-25$ & $14-26$ & $25-30$ & $15-26$ \\
\hline Mean rainfall (mm) & 670 & 888 & 890 & 785 & 670 \\
\hline
\end{tabular}

Source of vegetation and dominant plant species: adopted from Mucina and Rutherford, 2006. 


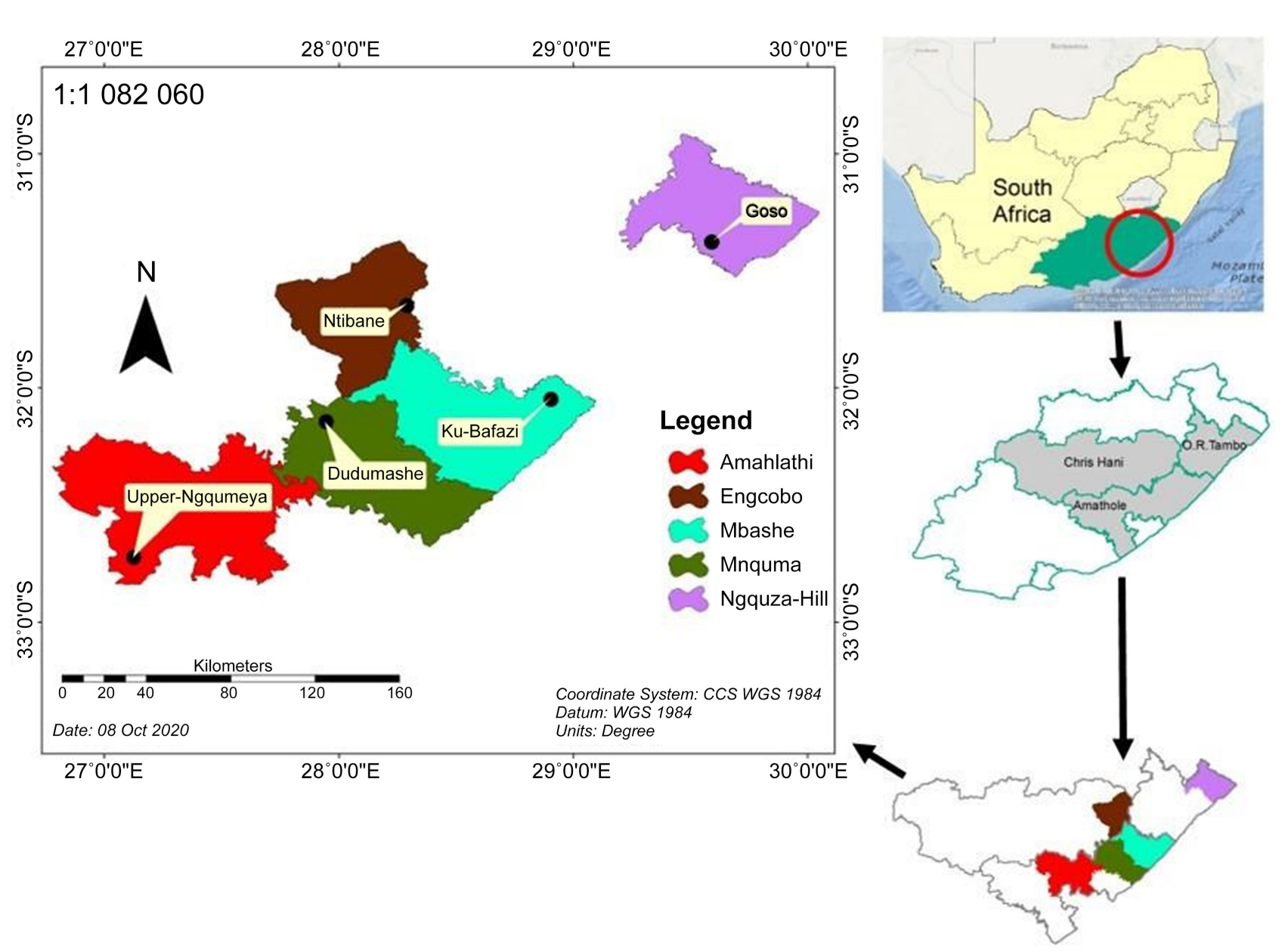

Figure 1 . Locality map showing the five villages.

demographic characteristics, land ownership status, contact with extension personnel, involvement in farming activities, funding, and constraints. The interviews were conducted using the vernacular Xhosa language but later translated to English.

\subsection{Statistical Analysis}

Collected data were analysed using the Statistical Analysis System of 2003, version 9.1 [18]. Frequencies were determined using the PROC FREQ procedures [18]. The chi-square test was used to determine associations between the youth and their involvement in agricultural activities. Statistical significance was tested at $95 \%$ level, with all results with $\mathrm{P}<0.05$ considered statistically significant.

\section{Results and Discussion}

\subsection{Gender, Age, Marital Status, and Education Level}

Table 2 showed that most respondents who participated in this study were male (59.6\%) compared to females (40.4\%). The dominance of male participation in agricultural activities aligned with the findings of [19] [20] [21] in Nigeria, Eastern 
Table 2. Demographic characteristics of the respondents.

\begin{tabular}{|c|c|c|c|}
\hline Category & Frequency $(\mathrm{n}=104)$ & Percentage & Significant levels \\
\hline Gender & & & NS \\
\hline Male & 62 & 59.6 & \\
\hline Female & 42 & 40.4 & \\
\hline Age (years) & & & * \\
\hline$<20$ & 27 & 26 & \\
\hline $20-35$ & 77 & 74 & \\
\hline Marital status & & & NS \\
\hline Single & 29 & 27.9 & \\
\hline Married & 49 & 47.1 & \\
\hline Divorced & 17 & 16.3 & \\
\hline Widow & 09 & 8.7 & \\
\hline Educational level & & & N.S. \\
\hline Primary & 14 & 13.5 & \\
\hline Senior secondary & 55 & 52.9 & \\
\hline Post matric & 35 & 33.6 & \\
\hline Household size & & & N.S. \\
\hline$<5$ & 39 & 37.5 & \\
\hline $6-10$ & 55 & 52.9 & \\
\hline$>10$ & 10 & 9.6 & \\
\hline Employment status & & & N.S. \\
\hline Employed & 22 & 21.2 & \\
\hline Self-employed & 82 & 78.8 & \\
\hline Family background & & & N.S. \\
\hline Agriculture & 92 & 88.5 & \\
\hline Non-agriculture & 12 & 11.5 & \\
\hline Income per annum & & & N.S. \\
\hline$<\mathrm{R} 20.000$ & 75 & 72.1 & \\
\hline R20.000 - R50.000 & 25 & 24 & \\
\hline$>$ R50.000 & 04 & 3.9 & \\
\hline Farming experience & & & $* *$ \\
\hline$<5$ & 54 & 51.9 & \\
\hline $5-10$ & 41 & 39.4 & \\
\hline$>10$ & 09 & 8.7 & \\
\hline
\end{tabular}

Significant at ${ }^{*} \mathrm{P} \leq 0.05,{ }^{* *} \mathrm{P} \leq 0.001$ and NS not significant at $\mathrm{P} \geq 0.05$.

Cape, and Tanzania, respectively. Similar trends were reported from surveys conducted in Tanzania, Ethiopia, and Nigeria, where men constituted a higher 
proportion than women [22] [23], reflecting the tendency towards male dominance in the livestock industry in most rural communities in Africa. This is contrary to a survey conducted by [24], who reported more than $50 \%$ of youth who participated in Zambia's agricultural activities were females. Less participation of females in the farming activities in the study areas might be due to females' involvement in other activities outside agriculture such as domestic activities (cleaning, cooking, and taking care of kids) and or non-farm activities (fashion design and hairdressing). Alternatively, it might result in males being more energetic and could be readily available for energy-demanding jobs related to farming, which tend not to attract females [25].

The most represented age group was 20 - 35 years old (74\%), followed by the age $<20$ years old $(26 \%)$ of the total sample (Table 2 ). These results concur with [25] [26], who reported that youth age above 20 years tends to dominate agricultural activities. This implied that respondents were mainly youth, going by the definition of youth as a person aged 14 and 35 years [27]. But [28] [29] [30] had different results in Nigeria, Pakistan, and South Africa, where the majority of youth involved in agricultural activities were in the age bracket of 15 to 22 years old. High involvement of youth above 20 years on-farm activities earns income to feed their families as most youths are married in the study areas. These findings also agreed with [30], who reported that rural youth families have long been directly and indirectly dependent on agriculture as a source of income for their livelihood.

About $47.1 \%$ of youth who participated in agricultural activities were married. This conformed with the findings of [31]. Contrarily with our findings, [32] reported a high percentage of youth that are single and involved in agricultural activities and perceived that high percentage of single youth might be due to lack of job or just starting on a new job and they do not want to be distracted with other activities. Table 2 reveals that $52.9 \%$ of youth attained senior secondary education, $33 \%$ having post-matric, and $13.5 \%$ had primary education. It is assumed that the more percentage of educated youth involved in different economic activities, there is likely to be more improvement in rural areas' development challenges. In agreement with [29], 29.3\% of youth interviewed were middle to matric, $26.7 \%$ were above matric, and $23.3 \%$ were up to primary education level. The present study's findings negate [24] results, finding that half $(50 \%)$ of the sampled youth had only attained primary education in Zambia.

\subsection{Household Size, Family Background, and Family Income per Annum}

Table 2 showed that most of the respondents (52.9\%) had household sizes comprising members 6 - 10, while others had 37.5\% and $9.6 \%$ had less than 5 and above 10 household sizes, respectively. The mean family size was 5.3 members per household with a standard deviation of 2.8 . The figure obtained in this sur- 
vey was higher than the provincial and national average family size of 3.9 and 3.3, respectively [9]. Contrary to our findings, [33] reported that Somalia's average family size was 5.9 people in a household. In general, family size differences may be attributed to the low level of family planning awareness in rural areas. Alternatively, many household members might be advantageous in providing labour to perform various agricultural activities.

Our study also observed that more than $80 \%$ of the youth belong to families with a farming background, whereas only $11.5 \%$ belong to families with a non-farming experience. This implied that most youth might have gotten the inspiration to be involved in agriculture from their parents, who were also engaged in farming. This is in line with [34] findings that more than $80 \%$ of Pakistan's youth who participated in agriculture belong to families with farm backgrounds. [35] reported that parent's influence is considered an essential source of social capital.

Table 2 revealed that $72.1 \%$ of youths had an annual family income level < R20.000 while $24 \%$ has an income within R20.000 - R50.000 and 3.8\% had income above R50.000. In agreement with [36], who attributed that parent's contribution income increases youth involvement in agriculture activities by $0.2 \%$. High participation of youth in households where parents earn income rather than agricultural activities might be due to advanced technology like tractors rather than animals for soil preparation.

\subsection{Employment Status, Farming Experience, and Landholding}

Table 2 showed that most (78.8\%) of the youth were unemployed in the study areas. Similarly, [37] [38] reported high unemployed among youth in rural areas. High youth unemployment might lack job opportunities or skills and experience required in our study sites.

The majority of rural youth (51.9\%) had been involved in agriculture for less than 5 years (Table 2). Another 39.4\% had between 5 - 10 years, while the remaining $8.7 \%$ had above 10 years of farming experience. It is assumed that youth lacking experience might not have access to funding as they are incompetent. In contrast, youth with more than 5 years of farming experience can set realistic goals and are more committed to various farming activities. [39] [40] had different results when only most youth had $6-10$ years and $11-15$ years of farming experience in Imo and Katsina, Nigeria.

Land ownership is an essential asset for young people trying to earn a living in agriculture. The overall average landholding per household in the study area was 2.1 hectares (Figure 2). However, the average landholding per household varied among different gender, age group, farming enterprise, and family size. A significant proportion of land in the study area was allocated for homestead (55\%), followed by crop and vegetable production (30\%) and rangelands (10\%). A possible reason for this might be due to an increase in the human population, unfavorable land tenure systems, and customary practices. The findings concurred 


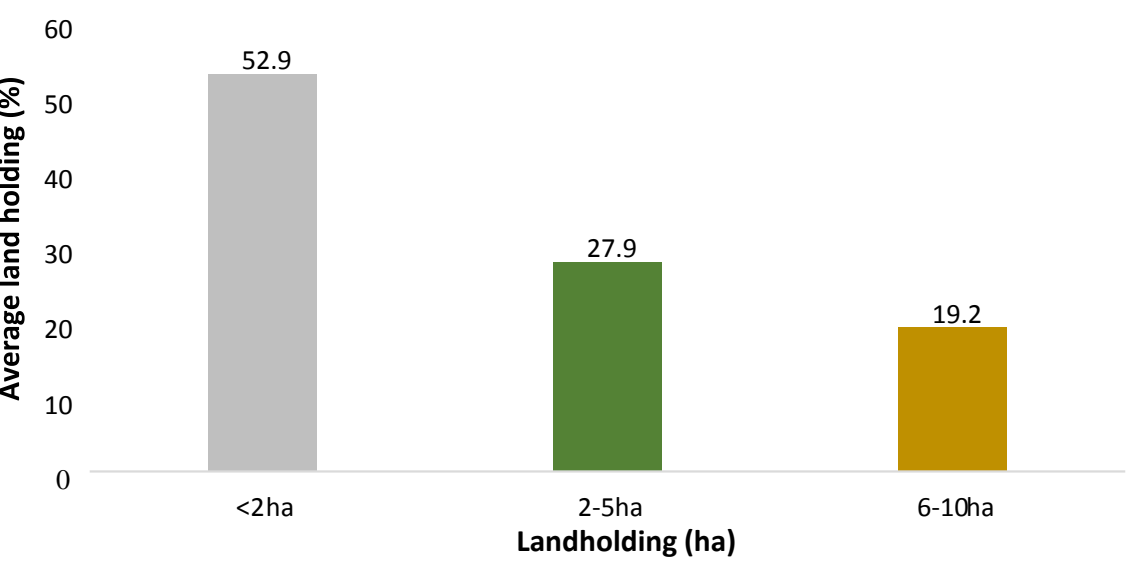

Figure 2. Landholding.

with those reported by [41] in Kenya, where the average farm size per household in 2010 was 2.1 ha.

\subsection{Association between Youth Demographic Information and Farm Enterprise and Contact with Extension Personnel}

The association between youth demographic information, farm enterprise, and contact with extension personnel is shown in Table 2. Age $\left(\chi^{2}=5.519, \mathrm{P}<0.01\right)$ and farming experience $\left(\chi^{2}=43.981, P<0.001\right)$ had a significant association with contact with extension personnel and farm enterprise, respectively. There was no significant difference between farm enterprise and contact with extension personnel with gender, marital status, educational level, household size, employment status, family background, and income per annum.

\subsection{Youth Contact with Extension Personnel}

The majority of youth $(70 \%)$ did not have extension contact in the past six months, while $30 \%$ had extension contact (Figure 3 ). This may be attributed to the low extension-farmer ratio. Lack of access to extension services deprives the youth of embracing improved technologies that will boost their productivity in family farming, especially those coming to a household with a primary income and no family farm background.

\subsection{Youth Involvement in Agriculture and Other Activities}

The results in Table 3 indicate that more than 50 percent of the youth were involved in vegetable and crop production, while $32.7 \%$ were in livestock and $10.6 \%$ in non-farming activities. Youth participation in agricultural activities is important for ensuring sustainable agricultural and rural development and food security [42]. More involvement of youth in vegetable and crop and livestock production might be due to the availability of arable land for production. It was also observed that youth are involved in non-farming activities such as fashion design and bricklaying. Due to agriculture's physical nature, females have more 


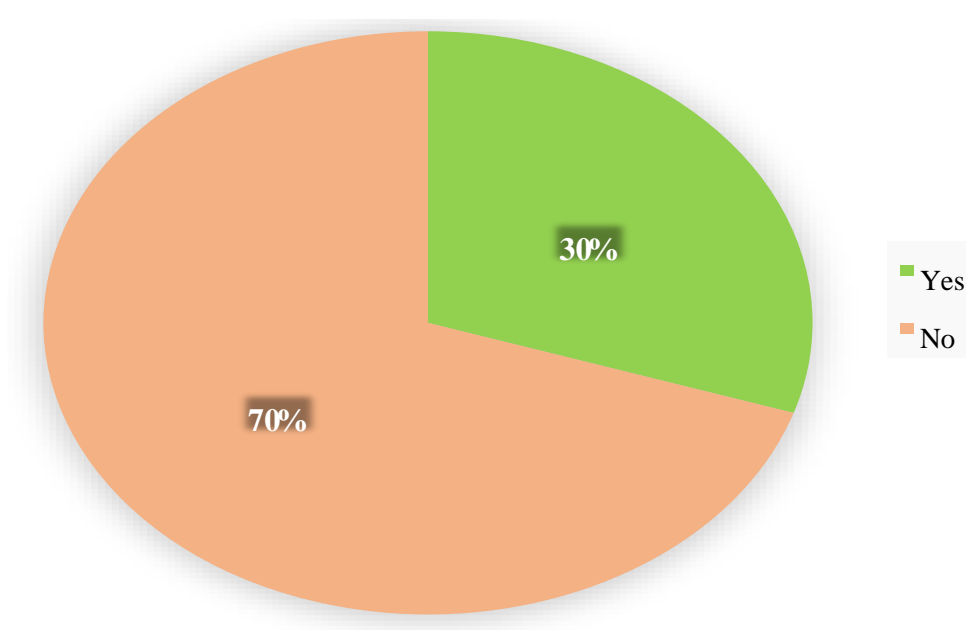

Figure 3. Youth contact with extension personnel.

Table 3. Youth involvement in farming activities.

\begin{tabular}{ccc}
\hline Variables & & Farming activities \\
\cline { 2 - 3 } & Frequency $(\mathrm{n}=104)$ & Percentage (\%) \\
\hline Vegetable and crop production & 59 & 56.7 \\
Livestock farming & 34 & 32.7 \\
Non-farming activities & 11 & 10.6 \\
Total & 104 & 100 \\
\hline
\end{tabular}

strength in planting, removing weeds, harvesting, feeding poultry and pigs, and marketing agricultural products. Males have more strength in activities that need intensive physical labour, such as planting, irrigation, herding of cattle, and milking.

\subsection{Sources of Funding for Farm Activities}

Family support (38.5\%) followed by government (20.0\%), non-governmental organizations (24.0\%), and own savings (8.7\%) were the major source of funding for youth involvement in agricultural activities (Table 4). The observations agree with those reported by [43], who reported that the government is one of the major funding sources for any developmental programs in South Africa.

\subsection{Constraints of Rural Youth Involvement in Agriculture}

The results in Table 5 showed that land ownership (22\%), high inputs costs (17\%), access credit (15\%), visibility of extension personnel (15\%), access to market $(11 \%)$, and low returns $(8 \%)$ were the most rated constraints. This contrasts with [44], who reported that agricultural knowledge (26.7\%) was the most reported constraint by rural Punjab in Pakistan. Among the constraints, landownership, high inputs costs, and access credits were the most ranked hindering the youth involvement in agricultural activities (Table 5). In agreement with [28], 
Table 4. Sources of funding for agricultural activities.

\begin{tabular}{ccc}
\hline \multirow{2}{*}{ Variables } & \multicolumn{2}{c}{ Sources of funding } \\
\cline { 2 - 3 } & Frequency $(\mathrm{n}=104)$ & Percentage (\%) \\
\hline Government & 30 & 28.8 \\
NGO & 25 & 24.0 \\
Family support & 40 & 38.5 \\
Own savings & 09 & 8.7 \\
Total & 104 & 100 \\
\hline
\end{tabular}

Table 5. Constraints of rural youth involvement in agriculture and rural development.

\begin{tabular}{cccc}
\hline \multirow{2}{*}{ Variables } & \multicolumn{3}{c}{ Constraints } \\
\cline { 2 - 4 } & Frequency & Percentage (\%) & Rank \\
\hline Land ownership & 89 & 22 & 1 \\
Access to market & 45 & 11 & 4 \\
Access to credit & 62 & 15 & 2 \\
Farming knowledge & 11 & 5 & 7 \\
High-cost mechanization & 30 & 7 & 5 \\
Visibility of extension personnel & 62 & 15 & 3 \\
High input costs & 70 & 17 & 6 \\
Low returns & 34 & 8 & \\
Totals & 403 & 100 & 2 \\
\hline
\end{tabular}

who rated difficulty accessing credits, lack of access to production inputs, and low returns as significant constraints to youth participation. However, these findings contradict [45], who stated that commitment is a major impendent. High costs of mechanization (7\%) and farming knowledge (5\%) were amongst the least rated constraints (Table 5). [46] highlighted that access to credits and land availability was amongst the most critical challenges facing rural youth in Nigeria. Visibility of extension personnel remains crucial for training and exposure to market access. However, poor visibility of extension personnel in this study hinders youth participation and capacity development agreement with [47]. I observed that increased agricultural productivity and improved income for the youth are achievable when effective extension personnel are put in place.

\section{Conclusion and Recommendations}

Regarding the participation of respondents in terms of agricultural activities, males were most dominant compared to females. Youth were also involved in non-agricultural activities such as bricklaying and fashion design to make a living. Lack of land ownership, high input costs, access to credit, and visibility of extension personnel, lack of market access, low returns, high cost of mechaniza- 
tion, and lack of farming knowledge were the most ranked constraints hindering youth involvement. Purchasing foundation stock, environmentally friendly breeds, caring for sick animals, planning for land preparation and planting dates, weeding, harvesting, and identifying markets to sell the produce were the least rated constraints preventing youth participation in agricultural activities in the study sites. Youth involvement in agriculture remains crucial for the better future of any country. Therefore, it is recommended that a robust relationship between agencies interested in encouraging youth involvement in agriculture should be evolved through legislation and implementation of policies to guarantee training programs, credit facilities, land accessibility to youths at the identified rural youth organizations. This will enhance youth involvement and catalyse agricultural development.

\section{Acknowledgements}

The authors are indebted to the youth in various communities for allowing us to do this research. We are also grateful to the Department of Rural Development and Agrarian Reform for the opportunity to conduct this research and also provide funding.

\section{Conflicts of Interest}

The authors declare no conflicts of interest regarding the publication of this paper.

\section{References}

[1] Alawa, D.A., Ajigo, I., Unimna, F., Udie, E.A. and Adie, J.B. (2020) Policies Initiatives for Improving the Contributions of University Agricultural Education and Extension Institutions to Environmental and Sustainable Development in Agriculture. Educational Research and Reviews, 15, 273-281. https://doi.org/10.5897/ERR2020.3990

[2] Kwenye, J.M. and Sichone, T. (2016) Rural Youth Participation in Agriculture: Exploring the Significance and Challenges in the Control of Agricultural Sector in Zambian. RUFORUM Working Document Series (ISSN 1607-9345) No. 14, 473-477.

[3] Adefalu, F.O., Adekunle, O.A., Oladipo, L.L., Adisa, R.S. and Fatoye, A.D. (2009) Constraints to Youth Involvement in Agricultural Production in Kwara State, Nigeria. Agricultural Extension, 13, 102-108. https://doi.org/10.4314/jae.v13i1.53885

[4] Cook, Y.F. (1996) Summary of Paper on Extension and Rural Youth Programme in Selected Countries. Pris: RYP.

[5] Adeogun, S.O. (2015) Participatory Diagnostic Survey of Constraints to Youth Involvement in Cocoa Production in Cross River State of Nigeria. Agricultural Sciences, 60, 211-225. https://doi.org/10.2298/JAS1502211A

[6] Isaac, F.O., Obioma, O.D. and Sallau, R. (2014) Assessment of Youth Involvement in Agricultural Production: The Case of Sabon-Gari Local Government Area of Kaduna State, Nigeria. International Journal of Agricultural Science, Research and Technology in Extension and Education Systems, 4, 163-171.

[7] United Nation Environmental Programme (UNEP) (2011) Towards a Green 
Economy: Pathways to Sustainable Development and Poverty Eradication-A Synthesis for Policy Makers.

[8] International Monetary Fund (IMF) (2012) International Jobs Report. Economist Intelligence Unit, Washington DC.

[9] Statistics South Africa (Stats SA) (2016) Republic of South Africa Annual Report. http://www.statssa.gov.za/?page id=368

[10] Moitui, J.N. (2019) Challenges and Opportunities in Agriculture for African Youth. Technical Report, 1-9.

[11] Moloi, M.J. (2010) A Comparison of Socioeconomic Characteristics That Determine the Farm Income of Emerging Livestock and Horticultural Farmers in South Africa. Doctoral Dissertation.

http://ulspace.ul.ac.za/bitstream/handle/10386/100/moloi\%20mj.pdf?sequence=1\&i sAllowed $=\mathrm{y}$

[12] Anyike, O.O. (2011) Contract Farming in Developing Emerging Farmers in South Africa: Exploring the Gledhow Mansomini Sugarcane Scheme. Master's Thesis, University of Stellenbosch, Stellenbosch.

[13] Statistics South Africa (Stats SA) (2019) Mid-Year Population Estimates.

[14] Tobgay, S. (2005) Agriculture Diversification in Bhutan. Ministry of Agriculture, Thimphu.

[15] World Bank (2008) World Development Report 2008. Agriculture for Development. World Bank, Washington DC.

[16] Kimaro, P.J., Towo, N.N. and Moshi, B.H. (2015) Economics, Commerce and Management. Determinants of Rural Youth's Participation in Agricultural Activities, 3, 1-47.

[17] Afande, F.O., Maina, W.N. and Maina, M.P. (2015) Youth Engagement in Agriculture in Kenya: Challenges and Prospects. Journal of Culture, Society and Development, 7, 4-20.

[18] Statistical Analysis System (SAS) (2003) Statistical Analysis System Institute Inc. Users Guide, Version 9, Carry, NC, USA.

[19] Angba, A.O., Adesope, O.M. and Aboh, C.L. (2019) Effect of Socioeconomic Characteristics of Rural Youths on Their Attitude towards Participation in Community Development Projects. International NGO Journal, 4, 348-351.

[20] Mapiliyao, L., Pepe, D., Chiruka, R., Marume, U. and Muchenje, V. (2013) Production Practices and Constraints to Sheep Productivity in Two Ecologically Different and Resource-Poor Communal Farming Systems of South Africa. Scientific Research and Essays, 7, 3209-3217. https://doi.org/10.5897/SRE12.140

[21] Jayapuria, D. (2015) A Study on Attitude of Rural Youth Regarding Participation in Agricultural Activities of Patan Block of Jabalpur District (MP). Doctoral Dissertation, M.Sc. Thesis, Jawarlal Nehru Krishi Vishva Vidyalaya.

[22] Maeda-Machangu, A.D., Mutayoba, S.K., Laswai, G.H., Mwaseba, D., Kimambo, A.E. and Lazaro, E. (2000) Local Knowledge and Gender Roles in Different Livestock Production Systems in Tanzania. Proceedings 1 st University-Wide Scientific Conference, Morogoro, 5-7 April 2000, 657-674.

[23] Adedeji, O.S., Akande, T.O., Akinwumi, A.O., Okunlola, D.O. and Shittu, M.D. (2013) Ethnoveterinary Practices among Sheep Rearers in Ona-Ara Local Government of Oyo State, Nigeria. Sokoto Journal of Veterinary Sciences, 11, 38-44. https://doi.org/10.4314/sokjvs.v11i1.6 
[24] Trevor, S. and Musole, K.J. (2018) Rural Youth Participation in Agriculture in Zambia. Journal of Agricultural Extension, 22, 52-63. https://doi.org/10.4314/jae.v22i2.5

[25] Charles, B. (2014) Assessment of the Youth in Agriculture Programme in Ejura-Sekyedumase District. MSc Thesis, Kwame Nkrumah University of Science and Technology, Ghana.

[26] Muhammad-Lawal, A.O., Omotosho, O.A. and Falola, A. (2009) Technical Efficiency of Youth Participation in Agriculture: A Case Study of the Youth-in-Agriculture Programme in Ondo State, South Western Nigeria. Nigerian Journal of Agriculture, Food and Environment, 5, 20-26.

[27] National Youth Commission Act, No. 19 of 1996 (1996) Government Gazette. General Notice No. 633. Government Printer, Pretoria.

https://doi.org/10.1016/S0277-5395(96)00066-0

[28] Adekunle, O.A., Adefalu, L.L., Oladipo, F.O., Adisa, R.S. and Fatope, A.D. (2012) Constraints to Youths Involvement in Agricultural Production in Kware State. Journal of Agricultural Extension, 13, 92-118. https://doi.org/10.4314/jae.v13i1.53885

[29] Butt, T.M., Hassan, M.Z.Y., Sahi, S.T., Atiq, M., Jabbar, A., Ahmad, I., Luqman, M. and Shafique, W. (2011) Role of Rural Youth in Agricultural and Rural Development: A Self-Perceived Case Study of Okara District, Punjab, Pakistan. Journal of Agricultural Extension and Rural Development, 3, 23-28.

[30] Nataraju, M.S. (2015) A Study on Perception, Aspiration and Participation of Farm Youth in Agriculture. Doctoral Dissertation, University of Agricultural Sciences Gkvk, Bengaluru.

[31] Ayanwuyi, E., Akinboye, O.A. and Olaniyi, O.A. (2007) Youth Participation in Rural Development Projects in Surulere Local Government Area of Oyo State, Nigeria. Social Sciences, 2, 312-317.

[32] Ogunremi, O.O., Ogunremi, J.B. and Faleyimu, O.I. (2012) Relevance and Benefits of Agricultural Youth Empowerment Programme to Participating Youth in Osun State, Nigeria. Asian Journal Social Sciences \& Humanities, 1, 7-19.

[33] United Nations (UN) (2017) Household Size and Composition around the World. Economic and Social Affairs.

https://www.un.org/en/development/desa/population/publications/pdf/ageing/hous ehold size and composition around the world 2017 data booklet.pdf

[34] Idrees, M. (2013) Developing a Strategy for Mobilising Rural Youth for the Development of Agriculture in NWFP, Pakistan. Doctor of Philosophy in Agricultural Extension, University of Agriculture, Fai.

[35] Kisingu, J.M. (2016) Factors Influencing Youth Participation in Agricultural Value Chain Projects in Kenya: A Case of Kathiani Sub-Country, Machakos Country, Kenya. MSc Thesis, University of Nairobi, Nairobi.

[36] Nnadi, F.N. and Akwiwu, C.D. (2008) Determinants of Youth's Participation in Rural Agriculture in Imo State, Nigeria. Journal of Applied Sciences, 8, 328-333. https://doi.org/10.3923/jas.2008.328.333

[37] Gaviglio, A., Filippini, R., Madau, F.A., Marescotti, M.E. and Dermartini, E. (2021) Technical Efficiency and Production of Farms: A per Urban Case Study Analysis. Agricultural and Food Economics, 9, 1-18. https://doi.org/10.1186/s40100-021-00181-9

[38] Douglas, K., Singh, A. and Zvenyika, K. (2017) Perceptions of Swaziland's Youth 
towards Farming: A Case of Manzini Region. Forestry Research and Engineering: International Journal, 1, 1-8. https://doi.org/10.15406/freij.2017.01.00014

[39] Ezeano, C.I., Ume, S.I., Okeke, C.C. and Gbughemobi, B.O. (2017) Socio Economic Determinants Factors to Youth's Participation in Broiler Production in Imo State of Nigeria. International Journal of Research and Review, 4, 136-143.

[40] Olatinwo, L.K., Fawole, B.E. and Akinyemi, M. (2017) Constraints of Rural Youth's Participation in Agricultural Development in Dutsin-Ma Local Government Area of Katsima State, Nigerian. Journal of Agriculture and Human Ecology, 1, 1-11.

[41] Jayne, T.S., Chapoto, A., Sitko, N., Nkonde, C., Muyanga, M. and Chamberlin, J. (2014) Is the Scramble for Land in Africa Foreclosing a Smallholder Agricultural Expansion Strategy? Journal of International Affairs, 67, 35-53.

[42] Lyocks, L., Lyocks, S. and Kagbu, J. (2013) Mobilizing Youth for Participation in Nigeria Agricultural Transformation Agenda: A Grassroots Approach. Journal of Agricultural Extension, 17, 77-88. https://doi.org/10.4314/jae.v17i2.11

[43] Mayer, M.J., Gordan, S., Manxeba, R., Hughes, C., Foley, P., Maroc, C., Lolwana, P. and Nell, M. (2011) Towards Youth Employment Strategy for South Africa. Development Bank of Southern Africa, Johannesburg.

[44] Hassan, M.Z.Y., Luqman, M., Ashraf, S., Yasin, N.M. and Raza, M.M. (2016) Constraints of Rural Youth Involvement in Agricultural Activities in the Punjab Pakistan: Redefining Youth Policy. Journal of Agricultural Research, 54, 861-871.

[45] Daudu, S., Okweche, V.A. and Adegboye, O.G. (2009) Role of Youth in Agricultural Development in Makurdi Local Government Are of Benue State. Journal of Agricultural Extension, 13, 107-112. https://doi.org/10.4314/jae.v13i2.53906

[46] Akpan, S.B. (2010) Encouraging Youth Involvement in Agricultural Production and Processing in Nigeria. Policy Note, 29, International Food Policy Research Institute, Washington DC.

[47] Mgbenka, R.N. (2015) Role Performance of Local Government Councils in Agricultural Development in South-East Nigeria. PhD Dissertation, Department of Agricultural Extension, University of Nigeria, Nsukka. 